Published in final edited form as:

Oral Oncol. 2017 June ; 69: 1-10. doi:10.1016/j.oraloncology.2017.03.020.

\title{
Establishment and characterization of an oral tongue squamous cell carcinoma cell line from a never-smoking patient
}

\author{
Steven J. Wang ${ }^{a, b}$, Saurabh Asthana ${ }^{b}$, Annemieke van Zante ${ }^{c}$, Chase M. Heaton ${ }^{a, b}$, \\ Janyaporn Phuchareon ${ }^{a, b}$, Leighton Stein ${ }^{d}$, Saito Higuchi ${ }^{b}$, Tomoya Kishimoto ${ }^{b}$, Charles $Y$. \\ Chiu $^{\mathrm{e}}$, Adam B. Olshen ${ }^{\mathrm{b}, \mathrm{f}}$, Frank McCormick ${ }^{\mathrm{b}}$, and Osamu Tetsu ${ }^{\mathrm{a}, \mathrm{b}, \mathrm{g}}$ \\ aDepartment of Otolaryngology-Head and Neck Surgery, School of Medicine, University of \\ California, San Francisco, San Francisco, CA 94143 \\ bUCSF Helen Diller Family Comprehensive Cancer Center, School of Medicine, University of \\ California, San Francisco, San Francisco, CA 94143 \\ 'Department of Pathology, School of Medicine, University of California, San Francisco, San \\ Francisco, CA 94143 \\ dDepartment of Pathology and Laboratory Medicine, Roswell Park Cancer Institute, Buffalo, NY \\ 14263 \\ eDepartment of Laboratory Medicine, School of Medicine, University of California, San Francisco, \\ 94143 \\ fDepartment of Epidemiology \& Biostatistics, School of Medicine, University of California, San \\ Francisco 94143
}

\section{Abstract}

Objective-The rising incidence of oral tongue squamous cell carcinoma (OTSCC) in patients who have never smoked and the paucity of knowledge of its biological behavior prompted us to develop a new cell line originating from a never-smoker.

Materials and methods-Fresh tumor tissue of keratinizing OTSCC was collected from a 44year-old woman who had never smoked. Serum-free media with a low calcium concentration were used in cell culture, and a multifaceted approach was taken to verify and characterize the cell line, designated UCSF-OT-1109.

Results-UCSF-OT-1109 was authenticated by STR DNA fingerprint analysis, presence of an epithelial marker EpCAM, absence of human papilloma virus (HPV) DNA, and SCC-specific microscopic appearance. Sphere-forming assays supported its tumorigenic potential. Spectral

${ }^{9}$ Correspondence to: Osamu Tetsu, MD, PhD, 1450 Third Street, UCSF Helen Diller Family Cancer Research Building, San Francisco, CA 94143-0128, USA. Osamu.Tetsu@ucsf.edu; Phone: 415-514-0870; Fax: 415-502-1712.

Conflict of interest statement

This work was supported in part by a grant from Roche Pharmaceuticals. No potential conflicts of interest were disclosed by the authors.

Publisher's Disclaimer: This is a PDF file of an unedited manuscript that has been accepted for publication. As a service to our customers we are providing this early version of the manuscript. The manuscript will undergo copyediting, typesetting, and review of the resulting proof before it is published in its final citable form. Please note that during the production process errors may be discovered which could affect the content, and all legal disclaimers that apply to the journal pertain. 
karyotype (SKY) analysis revealed numerical and structural chromosomal abnormalities. Wholeexome sequencing (WES) identified 46 non-synonymous and 13 synonymous somatic singlenucleotide polymorphisms (SNPs) and one frameshift deletion in the coding regions. Specifically, mutations of CDKN2A, TP53, SPTBN5, NOTCH2, and FAM136A were found in the databases. Copy number aberration (CNA) analysis revealed that the cell line loses chromosome $3 p$ and $9 p$, but lacks amplification of 3q and 11q (as does HPV-negative, smoking-unrelated OTSCC). It also exhibits four distinctive focal amplifications in chromosome 19p, containing 131 genes without SNPs. Particularly, 52 genes showed >3- to 4-fold amplification and could be potential oncogenic drivers.

Conclusion-We have successfully established a novel OTSCC cell line from a never-smoking patient. UCSF-OT-1109 is potentially a robust experimental model of OTSCC in never-smokers.

\section{Keywords}

Oral tongue squamous cell carcinoma; Never-smoker; Cell line; STR DNA fingerprint analysis; Sphere-forming assay; SKY analysis; Whole-exome sequencing; single nucleotide polymorphism; insertion or deletion; DNA copy number aberration

\section{Introduction}

Squamous cell carcinoma (SCC) of the tongue is classified into two subtypes, according to location [1,2]: oral tongue SCC (OTSCC), arising in the front two-thirds; and base-of-tongue SCC (BTSCC), originating in the posterior one-third (considered part of the oropharynx $[1])$.

OTSCC afflicts approximately 16,000 people a year in the US [3] and is typically related to a long history of smoking and/or heavy alcohol use [4]. Although US smoking rates continue to decline [5], the incidence of SCC of the oral cavity has remained stable [3]. This may be explained by an increase of OTSCC in patients who have never smoked or whose habit was light. These individuals, accounting for $~ 10 \%$ of OTSCC, are often women in their mid-forties or younger [4, 6-9]. Human papilloma virus (HPV) has been implicated in the recent rise in oropharyngeal cancers, including BTSCC [10, 11]. However, HPV infection does not explain the increase of never-smoker OTSCC because, regardless of smoking status, OTSCC patients are typically HPV-negative [12].

We recently reported that the never-smoking cohort may experience decreased survival and more aggressive characteristics than the smoking group [7-9]. However, it remains unclear what factors contribute to this poor clinical outcome [13]. One important way to gain insight into the behavior of OTSCC is to establish validated cell lines.

To date, most OTSCC cell lines have been generated from patients who were smokers, or whose smoking history is unknown, supporting the need for OTSCC cell lines verifiably developed from never-smoking patients. Such cells can be used as a platform to identify diagnostic biomarkers and evaluate novel therapeutic agents. 


\section{Materials and Methods}

\section{Tumor specimen and establishment of UCSF-OT-1109}

Under an approved Institutional Review Board (IRB) protocol (10-01635) and with informed consent, a portion of fresh tumor tissue was collected from a 44-year-old woman with invasive, keratinizing OTSCC who had never smoked. The tissue was divided into 3$\mathrm{mm}$ cubes; these were placed into $10-\mathrm{cm}$ dishes and maintained in a serum-free $154 \mathrm{CF}$ medium (M154CF500, Thermo Fisher Scientific, Waltham, MA) with $0.07 \mathrm{mM} \mathrm{Ca}^{2+}$ and growth supplements (both provided as separate components with the medium) in a $5 \% \mathrm{CO}_{2}$ incubator at $37^{\circ} \mathrm{C}$.

Fifty independent colonies were cloned. They were cultured continuously in serum-free medium Defined Keratinocyte-SFM (10744019, Thermo Fisher Scientific) in addition to growth supplements (10744019, Thermo Fisher Scientific; provided as a separate component with the medium), penicillin, and streptomycin. Each clone was passaged every seven days. After 20 passages, the cells were cultured in RPMI medium (11875-093, Thermo Fisher Scientific) containing 10\% fetal bovine serum (FBS) until passage 50 (p50). The established cell line was named UCSF-OT-1109 after the recommended style for cell-line designation of the International Cell Line Authentication Committee (ICLAC) [14].

\section{Cell culture}

The following cell lines were from the American Type Culture Collection: SCC-4, SCC-25, CAL27, HeLa, SW480, 293T, and WI-38. CAL27, HeLa, SW480, 293T, and WI-38 cells were cultured in RPMI 1640 medium (11875-093, Thermo Fisher Scientific) supplemented with 10\% FBS. SCC-4 and SCC-25 were cultured in DMEM: F12 HEPES medium (11330032, Thermo Fisher Scientific) containing $400 \mathrm{ng} / \mathrm{ml}$ hydrocortisone (H0888, Sigma Aldrich, St. Louis, MO) with $10 \%$ FBS. The cells were maintained in a $5 \% \mathrm{CO}_{2}$ incubator at $37^{\circ} \mathrm{C}$ [15]. Images were captured with EVOS cell imaging systems (Thermo Fisher Scientific).

\section{Short tandem repeat (STR) DNA fingerprint analysis}

Genomic DNA was isolated from the cultured cells (passage 5) and whole blood cells in a clean environment using the Wizard SV genomic DNA purification system (A2360, Promega Cooperation, Madison, WI) or DNeasy blood \& tissue kit (69504, Qiagen, Redwood City, CA). STR analysis was performed at the Johns Hopkins University Fragment Analysis Facility using the Powerplex 1.2 system (Promega Corporation) [16]. The following STR markers were tested: AMEL (Xp22.10-22.3 and Y), CSF1PO (5q33.3-34), D13S317 (13q22-q31), D16S539 (16q24-qter), D5S818 (5q21-q31), D7S820 (7q), TH01 (11p15.5), TPOX (2p23-2pter), and vWA (12p12-pter).

\section{Protein preparation and western blot analysis}

Total cellular protein was isolated with cell lysis buffer (9803, Cell Signaling Technology, Danvers, MA). Equal amounts of protein were prepared by adding reducing red loading buffer (7723, Cell Signaling Technology) and were resolved by SDS-PAGE (Novex TrisGlycine Gels, EC60055BOX, Thermo Fisher Scientific) [15]. Western blots were developed 
by enhanced chemiluminescence and detected by autoradiography film [15]. The following primary and secondary antibodies were used: EpCAM (NBP2-33051, Novus Biologicals, Littleton, CO), p16 INK4A (4824, Cell Signaling Technology), p53 (DO-1; sc-126, Santa Cruz Biotech), $\beta$-actin HRP-conjugated (A3854, Sigma Aldrich), CD44 (3570, Cell Signaling Technology), ALDH1A1 (12035, Cell Signaling Technology), anti-mouse IgG HRP (RPN4201, GE Healthcare Life Science, Pittsburgh, PA), and anti-rabbit IgG HRP (7074, Cell Signaling Technology).

\section{Immunohistochemistry}

For preparation of cytospins, single cell suspensions were spun onto slides using a cytocentrifuge (Thermo Fisher Scientific). Immunohistochemistry was subsequently performed on the slides with antibody-based staining kits for CD44 (3570, Cell Signaling Technology) at the UCSF Comprehensive Cancer Center Immunohistochemistry \& Molecular Pathology Core Facility. Staining was performed as previously described [17-19].

\section{PCR detection of HPV DNA}

Genomic DNA was isolated from the cultured cells. DNA samples were separately amplified by PCR with the primer sets:

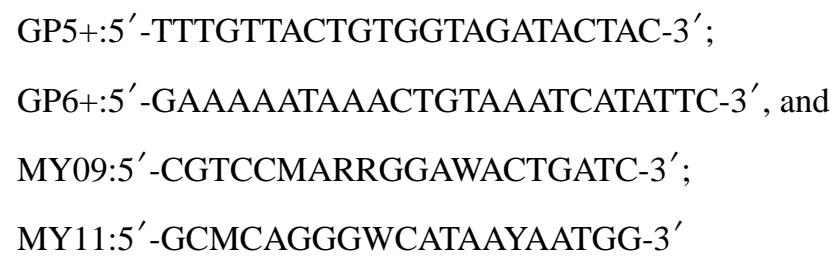

with proofreading capability Ex Taq DNA polymerase (RR001, Takara Bio USA, Mountain View, CA). The GP- and MY-PCR systems amplify approximately 150bp and 450bp DNA fragments, respectively, in the L1 region of HPV [20, 21]. PCR products were sequenced at Quintara Biosciences (South San Francisco, CA) to confirm that they contained the HPVspecific nucleotide sequence.

\section{Sphere-forming assay}

Single cell suspensions of UCSF-OT-1109 \#21 passage 25, CAL27 passage 27, or WI-38 passage 5 were prepared with TrypLE Express (12605010, Thermo Fisher Scientific) and a serum-free Defined Keratinocyte-SFM medium plus growth supplements (10744019, Thermo Fisher Scientific) [22]. Five thousand cells were distributed per well in sextuplicate using 6-well ultra-low-adherent plates (3471, Corning, Lowell, MA). After 10 days of incubation in a $5 \% \mathrm{CO}_{2}$ incubator at $37^{\circ} \mathrm{C}$, images were captured with EVOS cell imaging systems (Thermo Fisher Scientific) and the percentage of sphere-forming cells was calculated.

\section{Spectral karyotype (SKY) analysis}

SKY analysis was performed at the Roswell Park Cancer Institute Cytogenetics SKY Core Laboratory [23]. Exponentially growing UCSF-0T-1109 \#21 passage 25 cells were treated with colcemid (D1925, Sigma Aldrich) for 2 hours and metaphase chromosomes were air- 
dried on slides. After sequential digestion with RNase (R6513, Sigma Aldrich) and pepsin (P0525000, Sigma Aldrich), the chromosomal DNA was denatured in 70\% formamide (F9037, Sigma Aldrich) and hybridized with a cocktail of human SKY paint probes tagged with various nucleotide analogues (Applied Spectral Imaging, Inc., Carlsbad, CA). The slides were observed and scored under a fluorescent microscope (Nikon Instruments Inc., Melville, NY).

\section{Whole-exome sequencing (WES)}

Genomic DNA was extracted from UCSF-OT-1109 \#21 passage 5 cells and the tissue donor's blood cells as described above. DNA library preparation and subsequent targeted enrichment were carried out using TruSeq DNA library preparation kit (FC-121-2001, Illumina Inc., San Diego, CA) and SureSelect 50 Mb exome capture kit (5190-8863, Agilent Technologies, Santa Clara, CA). Exome-enriched products were sequenced using an Illumina HiSeq 2000 (Illumina, Inc., San Diego, CA) by Centrillion Biosciences Inc. (Mountain View, CA) [24, 25]. 100bp paired-end reads were aligned to NCBI build 37 (hg19) of the human genome using Burrows-Wheeler Aligner-Maximal Exact Matches (BWA-MEM) software; duplicate reads were marked, single nucleotide polymorphisms (SNPs) and local insertion or deletion (In/Del) realignment performed, and base-quality scores recalibrated for each sample with PICARD, SAMTOOLS and GATK programs. Novel point mutations and In/Dels were identified (with MuTect and GATK Somatic In/Del Detector, respectively) in tumor samples when compared with the donor's blood cells [26]. Copy number segmentation was performed on the log tumor/donor's blood cells per-exon coverage ratio using CNAKit and the R package 'DNAcopy' [27, 28].

\section{TP53-targeted sequencing}

Genomic DNA from UCSF-OT-1109 \#21 passage 25 cells was extracted as described above. Genomic DNA from the primary tumor was isolated from microdissected formalin-fixed, paraffin-embedded (FFPE) tissue sections using a QIAamp DNA FFPE Tissue kit (Qiagen). DNA samples were amplified by PCR with the primer set: p53 exon 7 forward: $5^{\prime}$ -

AAGGCGCACTGGCCTCATCTT- ${ }^{\prime}$; p53 exon 7 reverse: $5^{\prime}$ -

GAGGTGGATGGGTAGTAG- ${ }^{\prime}$ and proofreading capability Ex Taq DNA polymerase (RR001, Takara Bio USA). Direct sequencing of the PCR product was performed at Quintara Biosciences.

\section{Results}

\section{Cell-line tissue donor}

The donor, a 44-year-old woman who had never smoked and had no secondary smoke exposure presented with a painful right oral tongue lesion in 2009. On examination, a large right oral tongue mass was noted along with a palpable ipsilateral jugulodigastric lymph node. Biopsy of the lesion revealed invasive SCC. The patient underwent a right partial glossectomy, right neck dissection, and a radial forearm free-flap reconstruction in November, 2009. Final pathology revealed a 5-cm moderately-to-poorly differentiated invasive keratinizing SCC with perineural invasion (Figures 1A and B). Three (of 56) lymph nodes in the right neck were positive for carcinoma with extranodal extension. Final 
pathologic staging was T3N2bM0. The patient subsequently underwent adjuvant chemoradiation therapy with weekly cisplatin. She suffered no recurrence and is free of disease eight years later.

\section{Successful development of a novel OTSCC cell line, UCSF-OT-1109}

Contamination by host-derived stromal fibroblasts in cultured tumor cells represents a major obstacle in establishing cancer cell lines [29]. Thus, to inhibit overgrowth of fibroblasts, we used a serum-free medium formulated with a low calcium concentration. Among 50 independent colonies cloned from this tumor, five clones (\#6, \#20, \#21, \#22, and \#23) were able to proliferate after passage 5 .

To authenticate the cultured cells, we compared the STR profile of these five clones with that of peripheral blood cells from the tissue donor and found them to be identical, supporting their donor origin (Table 1). After 20 passages; we cultured the cells in regular medium containing FBS. The cells did not show senescence through 50 passages, supporting the successful development of a novel cell line.

\section{UCSF-OT-1109 cells are epithelium-derived, HPV-negative SCC}

The appearance of UCSF-OT-1109 clone \#21 at passage 25 differed depending on the presence or absence of serum, although both had microscopic characteristics of SCC [30]. In serum-free medium, the cells had a cuboidal epithelioid morphology and grew as a monolayer (Figure 1C); in serum-containing medium, they were pleomorphic, elongated, spread-out, and grew in a stratified pattern (Figure 1D).

To confirm that the cultured cells were of epithelial origin and not stromal fibroblasts, we analyzed expression levels of epithelial cell adhesion molecule (EpCAM; also known as CD326) [31]. We included other OTSCC cell lines SCC-4, SCC-25 and CAL27, the purported cervical cancer cell line HeLa [16], and a colon cancer cell line SW480. All but HeLa expressed EpCAM protein (Figure 1E).

Expression of p16 INK4A is frequently upregulated in cervical and oropharyngeal cancers, and is used clinically as evidence of HPV infection [32]. Given that OTSCCs are usually HPV-negative, UCSF-OT-1109 and other OTSCC cell lines do not overexpress p16 INK4A. The absence of HPV infection was confirmed by western blot analysis (Figure 1E), and further validated by a PCR-based method for HPV DNA detection (Figure 1F).

\section{UCSF-OT-1109 cells are capable of forming tumorigenic spheres}

We found that cytospins from UCSF-OT-1109 stained strongly positive with CD44, a marker for tumorigenic potential in head and neck SCC (HNSCC) [33] (Figure 2A). However, the tumorigenic potential of HNSCC may also require ALDH1A1 expression [34]. Western blots showed that UCSF-OT-1109 and other OTSCC cell lines, but not 293T cells, expressed both CD44 and ALDH1A1 (Figure 2B). These findings suggest that all five OTSCC cell lines may possess tumorigenic potential.

We therefore evaluated the adherent population of UCSF-OT-1109 \#21 passage 25, CAL27 passage 27, and WI-38 passage 5 cells for sphere formation. CAL27 cells are reported to 
form tumorigenic spheres [22], but WI-38 lung fibroblasts are non-tumorigenic [35]. Single cell suspensions of the cultured cells were seeded on ultra-low-adherent plate with a serumfree medium containing growth supplements. Sphere formation of UCSF-OT-1109 and CAL27 cells but not WI-38 cells was observed within 4 days; 10 days later, the OTSCC cells and fibroblasts had formed spheres of various sizes (Figures $2 \mathrm{C}-\mathrm{E}$ ). We designated successful sphere populations as those $>50 \mu \mathrm{m}$ in diameter for purposes of quantification, and calculated sphere-forming efficiency as the number of spheres divided by the total number of cells plated. We observed that UCSF-OT-1109, CAL27, and WI-38 cells possess a sphere-forming population of $0.82 \%, 0.46 \%$, and $0.13 \%$, respectively (Figure $2 \mathrm{~F}$ ).

\section{UCSF-OT-1109 retains numerical and structural chromosomal abnormalities}

In elucidating the genomic landscape of UCSF-OT-1109, our SKY analysis of 20 metaphases of the clone \#21 passage 25 cells [23] revealed that the cell line has an abnormal human female karyotype with a chromosome number ranging from 75-88 (Figures 3A-D). In addition, numerous structural abnormalities were observed: two copies of a translocation derived from a small portion of chromosome 12 within chromosome 1 [der(1)t(1:12)]; a translocation consisting of portions of chromosomes 1 and 9 [der(1)t(1:9)]; a translocation of portions of chromosomes 1 and 11 [der(1)t(1:11)] (appearing in only one of 20 cells analyzed) (Figure 3C); a translocation of portions of chromosomes 1 and 17 [der(1)t(1:17)] (in only one of 20 cells analyzed) (Figure 3C); two copies of a translocation of a very small portion of chromosome 1 and a larger portion of chromosome $3[\operatorname{der}(3) t(1: 3)]$; a deletion of a large portion of chromosome 5 [del(5)] (in one of 20 cells) (Figure 3D); one copy of chromosome 9 containing a dicentric centromere [dic(9)]; a translocation of portions of chromosomes 12 and 19 [der(19)t(12:19)]; one copy of chromosome 13 containing a duplication of the entire chromosome [dup(13)] (Figures 3A, B, and D); a translocation of almost equal portions of chromosomes 13 and 14 [der(13)t(13:14)]; a translocation of portions of chromosomes 14 and 19 [der(14)t(14:19)]; one copy of chromosome 16 containing a dicentric centromere [dic(16)]; a translocation of portions of chromosomes 16 and 19 [der(16)t(16:19)]; and a deletion of a portion of chromosome 19 [del(19)], which was observed in 8 of 20 cells (Figures 3B and C).

\section{UCSF-OT-1109 harbors 60 somatic mutations}

In WES of genomic DNA extracted from UCSF-OT-1109 \#21 passage 5, we used a paired comparison with blood cells from the tissue donor to distinguish somatic mutations and copy number aberrations in the tumor cells $[24,36,37]$.

WES yielded mean coverages of 23.72 and 20.28 times per base across the whole exome of UCSF-OT-1109 and control donor blood cells, respectively. We determined significant somatic mutations as variant read frequency (VRF) $>10 \%$, and found 60 somatically mutated coding genes (Supplemental Table 1).

Targeted sequencing confirmed the TP53 mutation in both the cell line and primary tumor: coding DNA sequence 743, guanine and adenine are switched in exon 7 (c.743G > A; Figures $4 \mathrm{~A}$ and $\mathrm{D}$ ). The reverse read verified the forward read (c.743C $>\mathrm{T}$; Figures $4 \mathrm{~B}$ and E). The 
predicted missense substitution was glutamine (Q) for arginine (R); p.Arg248Gln or R248Q, resulting in the protein stabilization (Figure 4C).

Likewise, mutations of CDKN2A, TP53, SPTBN5, NOTCH2, and FAM136A were found in the Single Nucleotide Polymorphism database (dbSNP) and/or Catalogue of Somatic Mutations in Cancer (COSMIC) (Supplemental Table 1). However, the other 55 mutations were novel. The NOTCH2 mutation suggested an inactive form because of the copy number loss.

\section{UCSF-OT-1109 has a unique mutational profile}

The mutations identified through WES were non-synonymous (46 genes) and synonymous (13 genes) somatic SNPs (Supplemental Table 1). Moreover, we specifically observed one frameshift deletion (Del); insertions (Ins) were not found. The SNPs were distributed throughout the genome (Figure 5A). The non-synonymous SNPs were predominantly found in 13 chromosomes (Figure 5B).

We next searched mutational profiles of other OTSCC cell lines in the Cancer Cell Line Encyclopedia (CCLE) database (https://portals.broadinstitute.org/ccle/home) and compared the mutational burden with UCSF-OT1109. The cell lines SCC-4, SCC-15, SCC-25, and CAL27 have missense mutations in TP53; SCC-9 has a missense mutation in TP53BP1. All of the cell lines lack PI3CA mutations. We found that these cell lines have comparable numbers of mutations in the 25-63 coding genes (Figure 5C). However, they consist of a significant portion (15-20 genes) of small insertions and deletions (In/Dels). In contrast, UCSF-OT-1109 has only one frameshift deletion, but no insertions. Thus, UCSF-OT-1109 contains the highest numbers of non-synonymous and synonymous SNPs.

\section{UCSF-OT-1109 exhibits distinctive focal amplifications in chromosome 19p}

WES analysis also revealed the tumor genome to have a high burden of both broad and focal DNA copy number aberrations (CNAs) (Figure 6A and Supplemental Table 2).

Specifically, chromosome 8p loss and 8q gain--frequently found in oral cancer--were observed in UCSF-OT-1109 [38]. Moreover, as in HPV-negative oral cancer [39], the cell line lost chromosome 3p and 9p. However, UCSF-OT-1109 lacks amplification of 3q and 11q--a hallmark of smoking-related HNSCCs [40].

UCSF-OT-1109 has unique focal CNAs in chromosome 19p. The magnified ideogram of chromosome 19 revealed the presence of four focal amplifications (R1-R4) in the short arm (Figure 6B; Supplemental Table 3). The regions contain 131 genes (Supplemental Table 3), which are not somatically mutated (Supplemental Table 1). Among them, 52 genes showed a $\log 2$ copy number ratio $>1.75$, which corresponds to 3 - to 4 -fold amplification. Particularly, NFIX, LYL1, and TRMT1 demonstrated the highest $\log 2$ ratio (3.18), matching 8- to 9-fold increases. Thus, the amplifications were high-level chromosomal segment gains [37].

Interestingly, chromosome 19p lost its copy number throughout the short arm, suggesting that the focal CNAs might occur in the translocated chromosomes but not in the original 
location. In fact, we observed various translocations of chromosome 19 in the cell line; $\operatorname{der}(19) \mathrm{t}(12: 19)$, der(14)t(14:19), and $\operatorname{der}(16) \mathrm{t}(16: 19)$ (see above and Figures 3A-D).

\section{Discussion}

Tobacco use has been linked to cancers of the upper aerodigestive tract [41]; in fact, approximately $90 \%$ of OTSCCs occur in patients who are active or previous smokers [4]. The subset of OTSCC patients who have never smoked $(\sim 10 \%)$ is significantly younger and more likely to be female [6-9].

Although HPV has recently been linked to oropharyngeal cancers, including BTSCC, it does not appear to play a significant role in OTSCC $[10,11]$. Our novel cell line UCSF-OT-1109 has no evidence of association with HPV.

Different oncogenic etiologies cause unique mutation patterns [42]. HPV infection induces activity of the APOBEC family of cytidine deaminases [4-9]. Accordingly, HPV-associated HNSCC often generates TCW mutations $(\mathrm{C}>\mathrm{T}$ and $\mathrm{C}>\mathrm{G}$ mutations at T-C-A/T [TCW] trinucleotides) [43]. As a result, APOBEC activation frequently causes oncogenic E542K (c. $1624 \mathrm{G}>\mathrm{A}$ ) and E545K (c.1633G > A) PIK3CA mutations in HPV-associated HNSCC [44].

UCSF-OT-1109 expresses wild-type PIK3CA. Moreover, as in HPV-negative oral cancer, it harbors a mutant form of p53 and loses chromosome 3p and 9p. Likewise, amplification of $3 q$ and $11 q-a$ hallmark of smoking-related HNSCC--is absent [40]. Thus, UCSF-OT-1109 may demonstrate a unique mutational profile independent of HPV-infection and tobacco smoking. In fact, the cell line has only one frameshift deletion, but no insertions. However, decreased In/Dels found in UCSF-OT-1109 might be attributed to a specific nature of the cell line, not to the common character of OTSCC in never-smokers. A recent report with the TCGA database showed that In/Del frequencies do not differ between smokers and neversmokers [45].

We have reported here that UCSF-OT-1109 exhibits distinctive focal amplifications in chromosome 19p. To the best of our knowledge, this is the first report highlighting 19p CNAs in OTSCC. Detection of focal CNAs--such as MYC and CCND1--often promotes our understanding of the genesis and development of cancer [46]. Moreover, the CNAs have enabled us to discover new driver genes (e.g. HER2 and EGFR) that could identify new subsets of cancer, resulting in development of novel therapeutic interventions [37]. We therefore chose one gene from each amplicon; ARRDC5 (Region 1), RAB3D (Region 2), NACC1 (Region 3), and KLF2 (Region 4) and compared the frequencies of their genetic alterations in cancers using the datasets from the cBioPortal for Cancer Genomics (http:// www.cbioportal.org/).

We found that the gene amplifications are often found in the major subsets of neuroendocrine prostate cancer (NEPC), ovarian serous cystadenocarcinoma, and breast and pancreatic cancers, but are rarely found in the TCGA HNSCC cohort (Supplemental Figure 1 A-D). Only two oral cancer cases of 279 HNSCCs show similar amplifications (Supplemental Figure 2). However, NACC1 expression is a molecular biomarker for OTSCC 
[47]. Thus, regardless of amplification of NACC1 and other CNA genes, their expression may be elevated by other mechanisms in OTSCCs. Further studies are warranted.

With this successful establishment of a novel OTSCC cell line, we believe that UCSFOT-1109 can be a robust experimental model of oral cavity carcinoma in never-smokers.

\section{Supplementary Material}

Refer to Web version on PubMed Central for supplementary material.

\section{Acknowledgments}

\section{Funding}

This work was supported by grants from Roche Pharmaceuticals and the Joan and Irwin Jacobs Fund of the Jewish Community Foundation to O.T. and the National Cancer Institute (1R35CA197709) to F.M. A.B.O. was supported by NIH grant 5P30CA082103.

The authors gratefully acknowledge Carola Ries of the Roche Innovation Center at Penzberg in Germany, David W. Eisele of the Johns Hopkins University, and Allan Balmain of the University of California, San Francisco for critical discussion and valuable suggestions. We are also grateful to Guochun Liao and Jaya Ramkumar of the Centrillion Technologies, the Johns Hopkins University Fragment Analysis Facility, and the UCSF Comprehensive Cancer Center Immunohistochemistry \& Molecular Pathology Core Facility for their support of whole-exome sequencing, STR analysis, and immunohistochemistry.

\section{References}

1. Tongue cancer. Cancer Research; UK: http://www.cancerresearchuk.org/about-cancer/cancers-ingeneral/cancer-questions/tongue-cancer

2. Shiboski CH, Schmidt BL, Jordan RC. Tongue and tonsil carcinoma: increasing trends in the U.S. population ages 20-44 years. Cancer. 2005; 103(9):1843-9. [PubMed: 15772957]

3. Cancer Facts \& Figures. American Cancer Society; 2016. http://www.cancer.org/acs/groups/content/ @ research/documents/document/acspc-047079.pdf

4. Sankaranarayanan, R., Ramadas, K., Amarasinghe, H., Subramanian, S., Johnson, N. Oral Cancer: Prevention, Early Detection, and Treatment. In: Gelband, H.Jha, P.Sankaranarayanan, R., Horton, S., editors. Cancer: Disease Control Priorities. 3. Vol. 3. Washington (DC): The International Bank for Reconstruction and Development / The World Bank; 2015 Nov 01. Chapter 5

5. Centers for Disease Control and Prevention. Current Cigarette Smoking Among Adults-United States, 2005-2014. Morbidity and Mortality Weekly Report. 2015; 64(44):1233-40. [PubMed: 26562061]

6. Patel SC, Carpenter WR, Tyree S, Couch ME, Weissler M, Hackman T, Hayes DN, Shores C, Chera BS. Increasing incidence of oral tongue squamous cell carcinoma in young white women, age 18 to 44 years. J Clin Oncol. 2011; 29(11):1488-94. [PubMed: 21383286]

7. Durr ML, van Zante A, Li D, Kezirian EJ, Wang SJ. Oral tongue squamous cell carcinoma in neversmokers: analysis of clinicopathologic characteristics and survival. Otolaryngol Head Neck Surg. 2013; 149(1):89-96. [PubMed: 23533221]

8. Durr ML, Li D, Wang SJ. Oral cavity squamous cell carcinoma in never smokers: analysis of clinicopathologic characteristics and survival. Am J Otolaryngol. 2013; 34(5):388-93. [PubMed: 23540889]

9. Heaton CM, Durr ML, Tetsu O, van Zante A, Wang SJ. TP53 and CDKN2a mutations in neversmoker oral tongue squamous cell carcinoma. Laryngoscope. 2014; 124(7):E267-73. [PubMed: 24431303]

10. Ernster JA, Sciotto CG, O’Brien MM, Finch JL, Robinson LJ, Willson T, Mathews M. Rising incidence of oropharyngeal cancer and the role of oncogenic human papilloma virus. Laryngoscope. 2007; 117(12):2115-28. [PubMed: 17891052] 
11. Chaturvedi AK, Engels EA, Pfeiffer RM, Hernandez BY, Xiao W, Kim E, Jiang B, Goodman MT, Sibug-Saber M, Cozen W, Liu L, Lynch CF, Wentzensen N, Jordan RC, Altekruse S, Anderson WF, Rosenberg PS, Gillison ML. Human papillomavirus and rising oropharyngeal cancer incidence in the United States. J Clin Oncol. 2011; 29:4294-301. [PubMed: 21969503]

12. Ramqvist T, Grün N, Dalianis T. Human papillomavirus and tonsillar and base of tongue cancer. Viruses. 2015; 7(3):1332-43. [PubMed: 25803099]

13. Dahlstrom KR, Little JA, Zafereo ME, Lung M, Wei Q, Sturgis EM. Squamous cell carcinoma of the head and neck in never smoker-never drinkers: a descriptive epidemiologic study. Head Neck. 2008 Jan; 30(1):75-84. [PubMed: 17694557]

14. International Cell Line Authentication Committee. Naming a Cell Line. http://iclac.org/wp-content/ uploads/Naming-a-Cell-Line_v1_6.pdf

15. Phuchareon J, McCormick F, Eisele DW, Tetsu O. EGFR inhibition evokes innate drug resistance in lung cancer cells by preventing Akt activity and thus inactivating Ets-1 function. Proc Natl Acad Sci U S A. 2015; 112(29):E3855-63. [PubMed: 26150526]

16. Phuchareon J, Ohta Y, Woo JM, Eisele DW, Tetsu O. Genetic profiling reveals cross-contamination and misidentification of 6 adenoid cystic carcinoma cell lines: ACC2, ACC3, ACCM, ACCNS, ACCS and CAC2. PLoS One. 2009; 4(6):e6040. [PubMed: 19557180]

17. Tetsu O, Phuchareon J, Chou A, Cox DP, Eisele DW, Jordan RC. Mutations in the c-Kit gene disrupt mitogen-activated protein kinase signaling during tumor development in adenoid cystic carcinoma of the salivary glands. Neoplasia. 2010; 12(9):708-17. [PubMed: 20824047]

18. Phuchareon J, van Zante A, Overdevest JB, McCormick F, Eisele DW, Tetsu O. c-Kit Expression is Rate-Limiting for Stem Cell Factor-Mediated Disease Progression in Adenoid Cystic Carcinoma of the Salivary Glands. Transl Oncol. 2014; 7(5):537-45. [PubMed: 25389449]

19. Phuchareon J, Overdevest JB, McCormick F, Eisele DW, van Zante A, Tetsu O. Fatty Acid binding protein 7 is a molecular marker in adenoid cystic carcinoma of the salivary glands: implications for clinical significance. Transl Oncol. 2014; 7(6):780-7. [PubMed: 25500088]

20. Qu W, Jiang G, Cruz Y, Chang CJ, Ho GY, Klein RS, Burk RD. PCR detection of human papillomavirus: comparison between MY09/MY11 and GP5+/GP6+ primer systems. J Clin Microbiol. 1997; 35(6):1304-10. [PubMed: 9163434]

21. Meneses Venceslau E, Muniz Bezerra M, Mota Lopes A, Vieira Souza E, Casimiro Onofre A, Moura de Melo C, de Lourdes Sierpe Jeraldo V, de Miranda Onofre F. HPV detection using primers MY09/MY11 and GP5+/GP6+ in patients with cytologic and/or colposcopic changes. Jornal Brasileiro de Patologia e Medicina Laboratorial. 2014; 50(4):280-5.

22. Shrivastava S, Steele R, Sowadski M, Crawford SE, Varvares M, Ray RB. Identification of molecular signature of head and neck cancer stem-like cells. Sci Rep. 2015; 5:7819. [PubMed: 25588898]

23. Chitta KS, Paulus A, Ailawadhi S, Foster BA, Moser MT, Starostik P, Masood A, Sher T, Miller KC, Iancu DM, Conroy J, Nowak NJ, Sait SN, Personett DA, Coleman M, Furman RR, Martin P, Ansell SM, Lee K, Chanan-Khan AA. Development and characterization of a novel human Waldenström macroglobulinemia cell line: RPCI-WM1, Roswell Park Cancer Institute Waldenström Macroglobulinemia 1. Leuk Lymphoma. 2013 Feb; 54(2):387-96. [PubMed: 22812491]

24. Campbell N, Sinagra G, Jones KL, Slavov D, Gowan K, Merlo M, Carniel E, Fain PR, Aragona P, Di Lenarda A, Mestroni L, Taylor MR. Whole exome sequencing identifies a troponin T mutation hot spot in familial dilated cardiomyopathy. PLoS One. 2013; 8(10):e78104. [PubMed: 24205113]

25. Faden DL, Asthana S, Tihan T, DeRisi J, Kliot M. Whole Exome Sequencing of Growing and NonGrowing Cutaneous Neurofibromas from a Single Patient with Neurofibromatosis Type 1. PLoS One. 2017; 12(1):e0170348. [PubMed: 28099461]

26. Cibulskis K, Lawrence MS, Carter SL, Sivachenko A, Jaffe D, Sougnez C, Gabriel S, Meyerson M, Lander ES, Getz G. Sensitive detection of somatic point mutations in impure and heterogeneous cancer samples. Nat Biotechnol. 2013; 31(3):213-9. [PubMed: 23396013]

27. Olshen AB, Venkatraman ES, Lucito R, Wigler M. Circular binary segmentation for the analysis of array-based DNA copy number data. Biostatistics. 2004; 5(4):557-72. [PubMed: 15475419] 
28. Talevich E, Shain AH, Botton T, Bastian BC. CNVkit: Genome-Wide Copy Number Detection and Visualization from Targeted DNA Sequencing. PLoS Comput Biol. 2016; 12(4):e1004873. [PubMed: 27100738]

29. Horikawa T, Norris DA, Zekman T, Morelli JG. Effective elimination of fibroblasts in cultures of melanocytes by lowering calcium concentration in TPA depleted medium following geneticin treatment. Pigment Cell Res. 1996; 9(2):58-62. [PubMed: 8857666]

30. Carey, TE. Head and Neck Tumor Cell Lines. In: Hay, RJ.Park, JG., Gazdar, A., editors. Atlas of Human Tumor Cell Lines. Academic Press; 1994. p. 79-120.

31. Went PT, Lugli A, Meier S, Bundi M, Mirlacher M, Sauter G, Dirnhofer S. Frequent EpCam protein expression in human carcinomas. Hum Pathol. 2004; 35(1):122-8. [PubMed: 14745734]

32. Chernock RD. Morphologic features of conventional squamous cell carcinoma of the oropharynx: 'keratinizing' and 'nonkeratinizing' histologic types as the basis for a consistent classification system. Head Neck Pathol. 2012 Jul; 6(Suppl 1):S41-7. [PubMed: 22782222]

33. Prince ME, Sivanandan R, Kaczorowski A, Wolf GT, Kaplan MJ, Dalerba P, Weissman IL, Clarke MF, Ailles LE. Identification of a subpopulation of cells with cancer stem cell properties in head and neck squamous cell carcinoma. Proc Natl Acad Sci U S A. 2007; 104(3):973-8. [PubMed: 17210912]

34. Krishnamurthy S, Dong Z, Vodopyanov D, Imai A, Helman JI, Prince ME, Wicha MS, Nör JE. Endothelial cell-initiated signaling promotes the survival and self-renewal of cancer stem cells. Cancer Res. 2010; 70(23):9969-78. [PubMed: 21098716]

35. Stanbridge E, Onen M, Perkins FT, Hayflick L. Karyological and morphological characteristics of human diploid cell strain WI-38 infected with mycoplasmas. Exp Cell Res. 1969; 57(2):397-410. [PubMed: 5347639]

36. Pabinger S, Dander A, Fischer M, Snajder R, Sperk M, Efremova M, Krabichler B, Speicher MR, Zschocke J, Trajanoski Z. A survey of tools for variant analysis of next-generation genome sequencing data. Brief Bioinform. 2014 Mar; 15(2):256-78. [PubMed: 23341494]

37. Krijgsman O, Carvalho B, Meijer GA, Steenbergen RD, Ylstra B. Focal chromosomal copy number aberrations in cancer-Needles in a genome haystack. Biochim Biophys Acta. 2014; 1843(11):2698-2704. [PubMed: 25110350]

38. Yong ZW, Zaini ZM, Kallarakkal TG, Karen-Ng LP, Rahman ZA, Ismail SM, Sharifah NA, Mustafa WM, Abraham MT, Tay KK, Zain RB. Genetic alterations of chromosome 8 genes in oral cancer. Sci Rep. 2014; 4:6073. [PubMed: 25123227]

39. Feller L, Khammissa RA, Wood NH, Lemmer J. Epithelial maturation and molecular biology of oral HPV. Infect Agent Cancer. 2009; 4:16. [PubMed: 19930727]

40. Cancer Genome Atlas Network. Comprehensive genomic characterization of head and neck squamous cell carcinomas. Nature. 2015; 517(7536):576-82. [PubMed: 25631445]

41. Pelucchi C, Gallus S, Garavello W, Bosetti C, La Vecchia C. Alcohol and tobacco use, and cancer risk for upper aerodigestive tract and liver. Eur J Cancer Prev. 2008; 17(4):340-4. [PubMed: 18562959]

42. Alexandrov LB, Nik-Zainal S, Wedge DC, Aparicio SA, Behjati S, Biankin AV, Bignell GR, Bolli N, Borg A, Børresen-Dale AL, Boyault S, Burkhardt B, Butler AP, Caldas C, Davies HR, Desmedt C, Eils R, Eyfjörd JE, Foekens JA, Greaves M, Hosoda F, Hutter B, Ilicic T, Imbeaud S, Imielinski M, Jäger N, Jones DT, Jones D, Knappskog S, Kool M, Lakhani SR, Lopez-Otin C, Martin S, Munshi NC, Nakamura H, Northcott PA, Pajic M, Papaemmanuil E, Paradiso A, Pearson JV, Puente XS, Raine K, Ramakrishna M, Richardson AL, Richter J, Rosenstiel P, Schlesner M, Schumacher TN, Span PN, Teague JW, Totoki Y, Tutt AN, Valdes-Mas R, van Buuren MM, van't Veer L, Vincent-Salomon A, Waddell N, Yates LR, Zucman-Rossi J, Futreal PA, McDermott U, Lichter P, Meyerson M, Grimmond SM, Siebert R, Campo E, Shibata T, Pfister SM, Campbell PJ, Stratton MR. Australian Pancreatic Cancer Genome Initiative; ICGC Breast Cancer Consortium; ICGC MMML-Seq Consortium; ICGC PedBrain. Signatures of mutational processes in human cancer. Nature. 2013; 500:415-21. [PubMed: 23945592]

43. Roberts SA, Lawrence MS, Klimczak LJ, Grimm SA, Fargo D, Stojanov P, Kiezun A, Kryukov GV, Carter SL, Saksena G, Harris S, Shah RR, Resnick MA, Getz G, Gordenin DA. An APOBEC cytidine deaminase mutagenesis pattern is widespread in human cancers. Nat Genet. 2013; 45(9): 970-6. [PubMed: 23852170] 
44. Henderson S, Chakravarthy A, Su X, Boshoff C, Fenton TR. APOBEC-mediated cytosine deamination links PIK3CA helical domain mutations to human papillomavirus-driven tumor development. Cell Rep. 2014; 7(6):1833-41. [PubMed: 24910434]

45. Alexandrov LB, Ju YS, Haase K, Van Loo P, Martincorena I, Nik-Zainal S, Totoki Y, Fujimoto A, Nakagawa H, Shibata T, Campbell PJ, Vineis P, Phillips DH, Stratton MR. Mutational signatures associated with tobacco smoking in human cancer. Science. 2016; 354(6312):618-622. [PubMed: 27811275]

46. Costa JL, Meijer G, Ylstra B, Caldas C. Array comparative genomic hybridization copy number profiling: a new tool for translational research in solid malignancies. Semin Radiat Oncol. 2008; 18(2):98-104. [PubMed: 18314064]

47. Sekine J, Nakatani E, Ohira K, Hideshima K, Kanno T, Nariai Y, Kagimura T, Urano T. Nucleus Accumbens-Associated Protein 1 Expression Has Potential as a Marker for Distinguishing Oral Epithelial Dysplasia and Squamous Cell Carcinoma. PLoS One. 2015; 10(7):e0131752. [PubMed: 26172271] 


\section{Highlights}

- An oral tongue squamous cell carcinoma cell line was developed from a never-smoker.

- The cell line UCSF-OT-1109 was authenticated by STR DNA fingerprint analysis.

- UCSF-OT-1109 harbored 60 somatically mutated coding genes.

- The genomic landscape was distinct from tobacco- or HPV-related oral cancer.

- $\quad$ The cell line exhibited distinctive focal amplifications in chromosome 19p. 
A

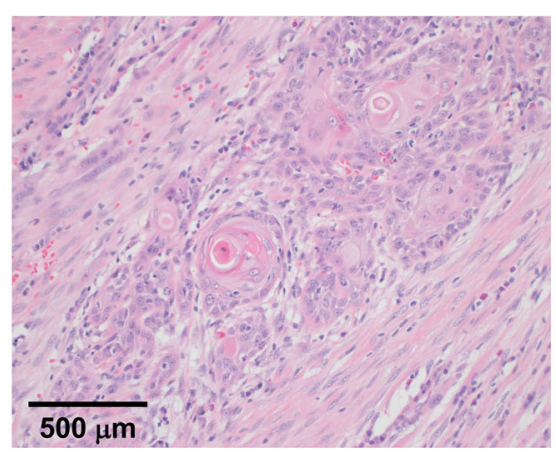

C

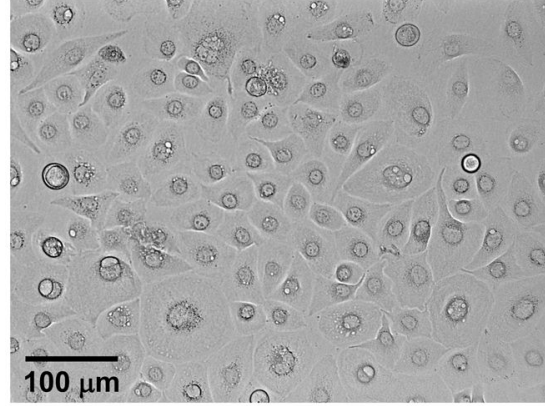

$\mathbf{E}$

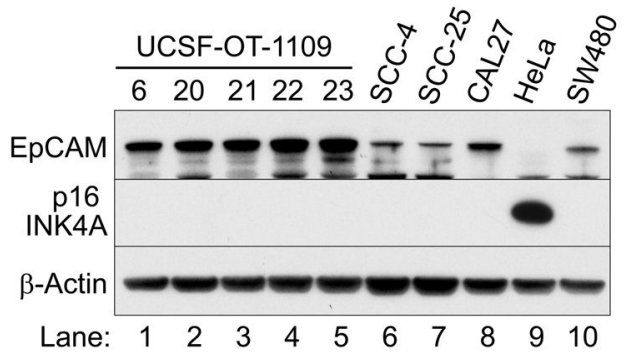

B

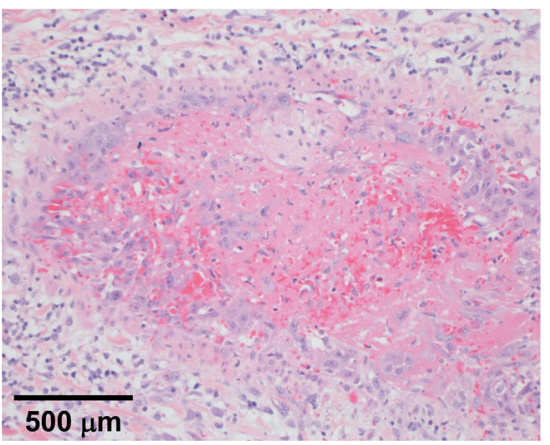

D

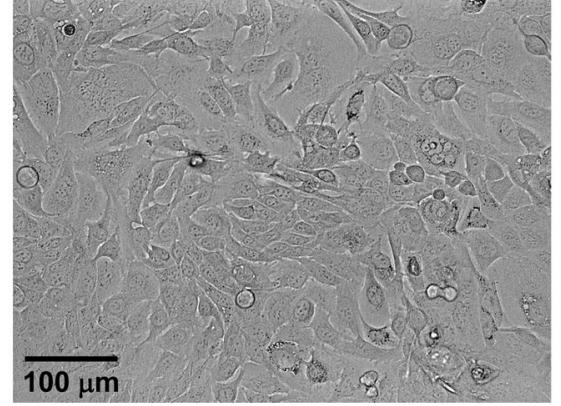

$\mathbf{F}$

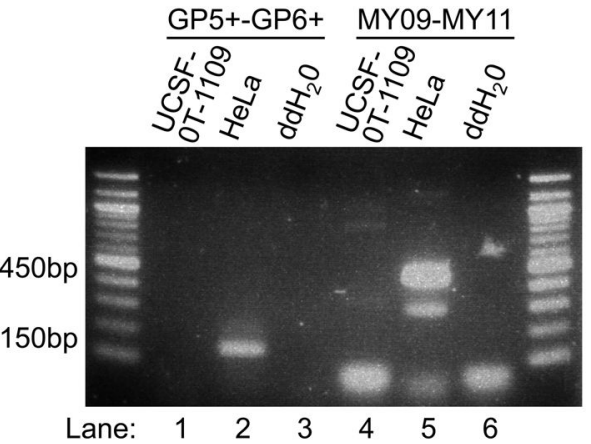

Figure 1. Establishment of UCSF-OT-1109

(A) Histologic sections of the primary oral tongue tumor showing invasive keratinizing squamous cell carcinoma (H \& E staining, x200).

(B) Histologic evaluation showing vascular invasion by tumor cells. A blood vessel is occupied by tumor cells at the periphery and fibrin clot (pink staining) containing red blood cells (strong red staining) centrally. The tumor cells form a vague layer around the fibrin clot. The vessel is surrounded by scant smooth muscle ( $\mathrm{H} \& \mathrm{E}, \mathrm{x} 400)$.

(C) (D) Cellular morphology of passage 25 of UCSF-OT-1109 clone \#21. The appearance of the cultured cells differs in the serum-free (C) and serum-containing (D) medium.

(E) Western blot analysis with epithelial cell adhesion molecule (EpCAM), p16 INK4A, and $\beta$-Actin antibodies: Lanes 1-5, UCSF-OT-1109 clone; Lanes 6-8, OTSCC cell lines; Lane 9, cervical cancer cell line HeLa; Lane 10, colon cancer cell line SW480. 
(F) PCR detection of HPV DNA samples from cultured cells were amplified by PCR with the primer set GP5+ and GP6+ or MY09 and MY11. The GP- and MY-PCR systems amplify approximately 150bp and 450bp fragments, respectively, in the L1 region of HPV. PCR was also carried out with double-distilled water $(\mathrm{ddH} 2 \mathrm{O})$ as a no-template negative control. 
A

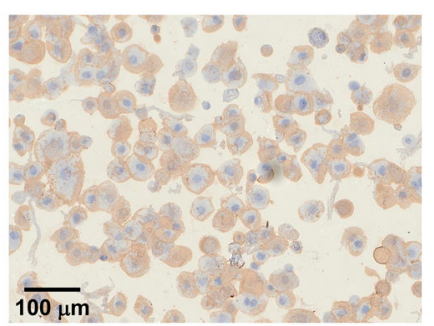

C

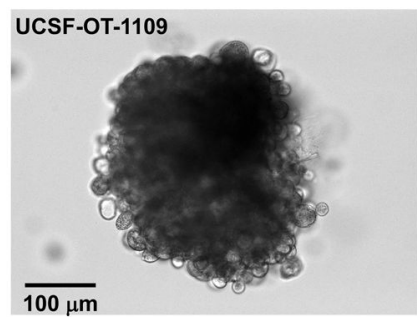

E

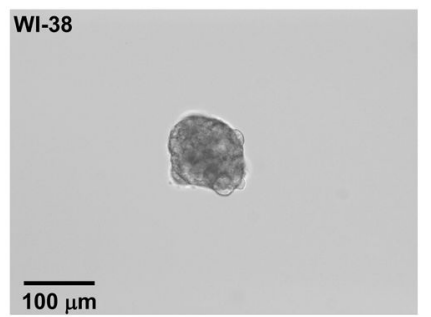

B

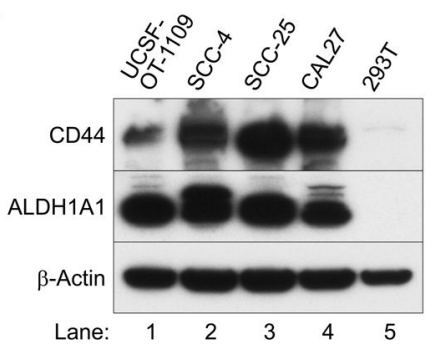

D

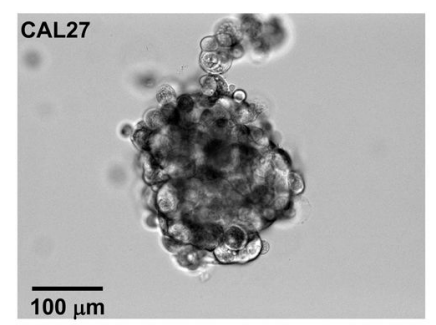

$\mathbf{F}$

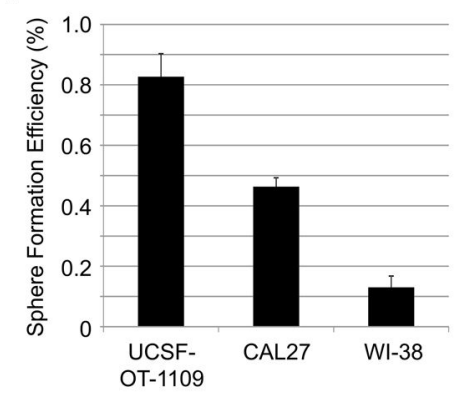

Figure 2. Tumorigenic sphere formation of UCSF-OT-1109

(A) Immunohistochemistry with a CD44 antibody on cytospins of UCSF-OT-1109 cells.

(B) Western blot analysis with CD44, ALDH1A1, and $\beta$-Actin antibodies.

(C)-(F) Sphere-forming assay. Single cell suspensions of UCSF-OT-1109 \#21, CAL27, and WI-38 were seeded on ultra-low-adherent plate with a serum-free medium containing growth supplements.

(C)-(E) Representative spheres of UCSF-OT-1109 (C), CAL27 (D), and WI-38 (E) cells on day 10 .

(F) Sphere-forming efficiency of UCSF-OT-1109, CAL27, and WI-38 (see text). 

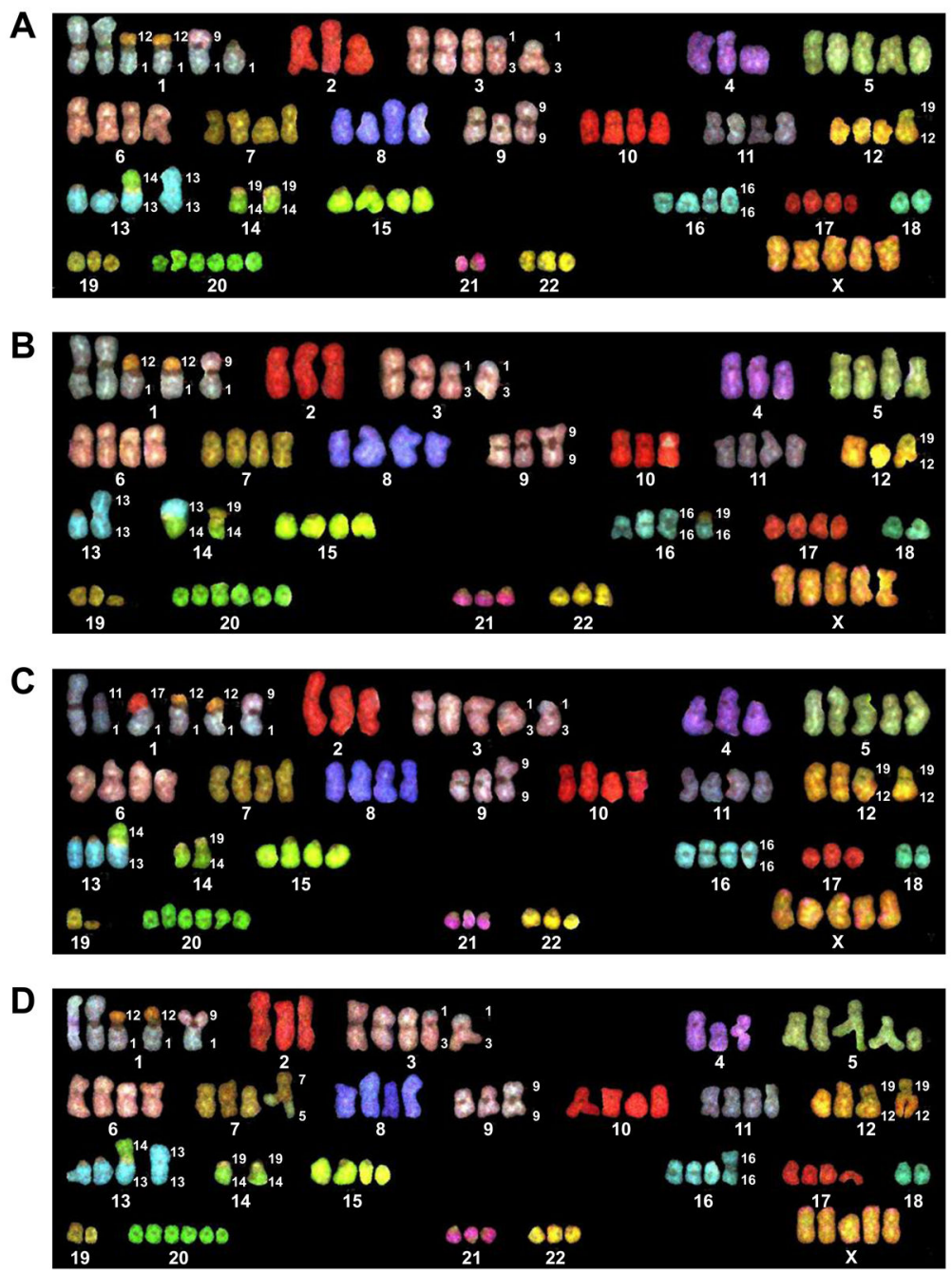

Figure 3. Numerical and structural abnormalities in UCSF-OT-1109 chromosome (A)-(D) SKY analysis; 20 metaphases of UCSF-OT-1109 clone \#21 passage 25 cells were analyzed. The cell line had an abnormal human female karyotype with a chromosome number ranging from 75-88. Numerous structural abnormalities were also observed (see text). 
A

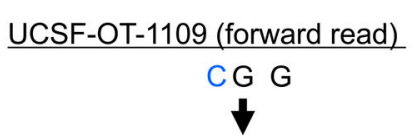

A T G A A CA G A G G C C

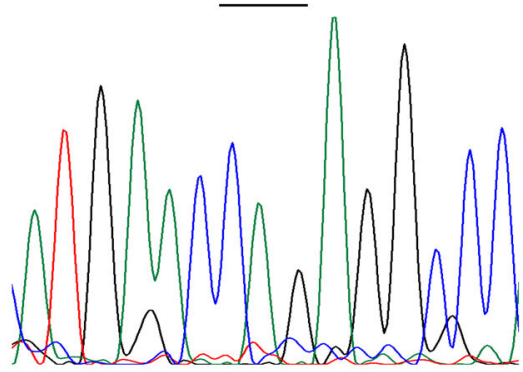

B

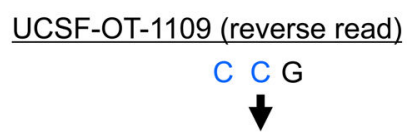

G G GC C T C T G G T T CA T

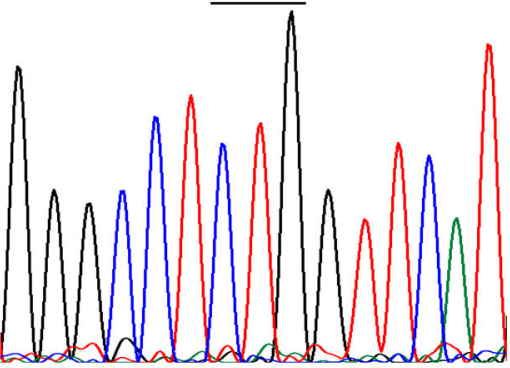

C

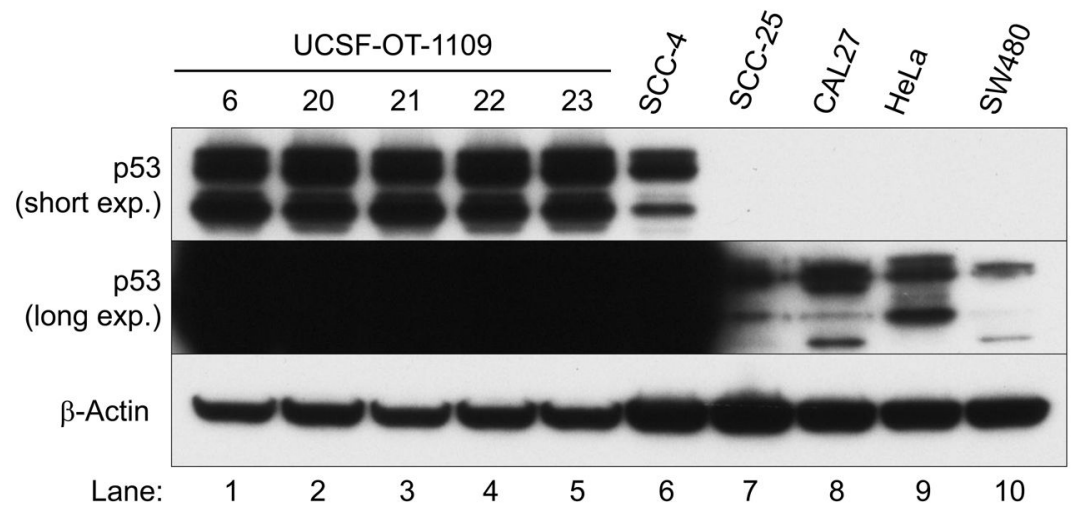

D

Primary tumor (forward read)

C G G

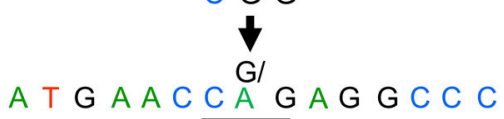

$\mathbf{E}$

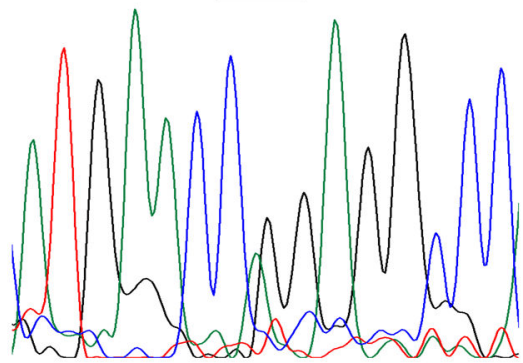

Primary tumor (reverse read)
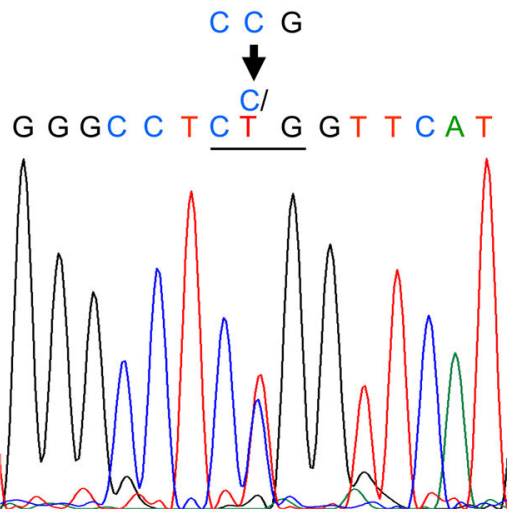

Figure 4. TP53-targeted sequencing of UCSF-OT-1109 (A, forward read; B, reverse read) and the primary tumor $(D$, forward read; $E$, reverse read)

(C) Western blot analysis with p53 (short and long exposure) and $\beta$-Actin antibodies: Lanes 1-5, UCSF-OT-1109 clone; Lanes 6-8, OTSCC lines, Lane 9, cervical cancer cell line HeLa; Lane 10, colon cancer cell line SW480.

In D and E, genomic DNA was isolated from microdissected FFPE tissue sections. 

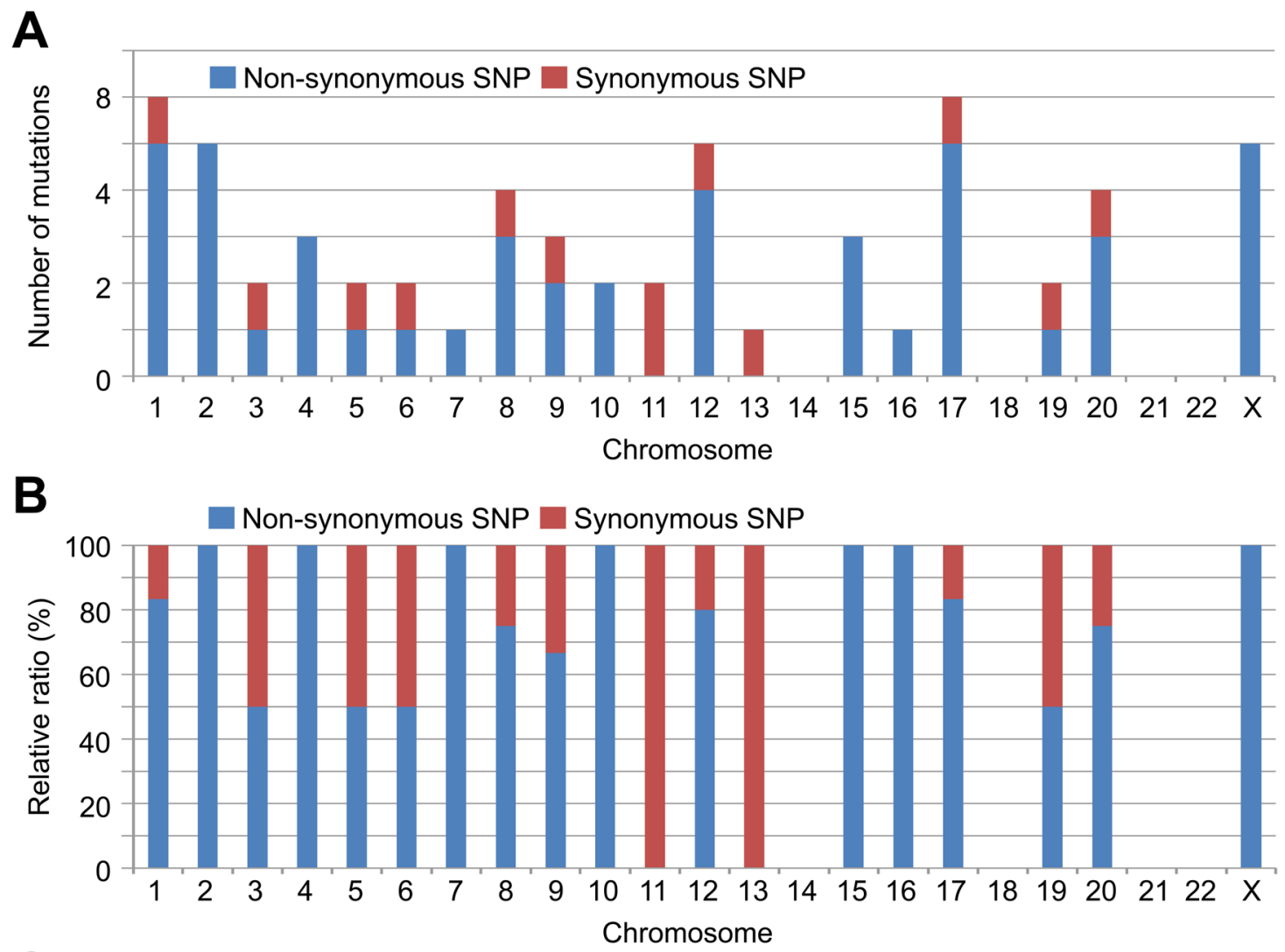

C

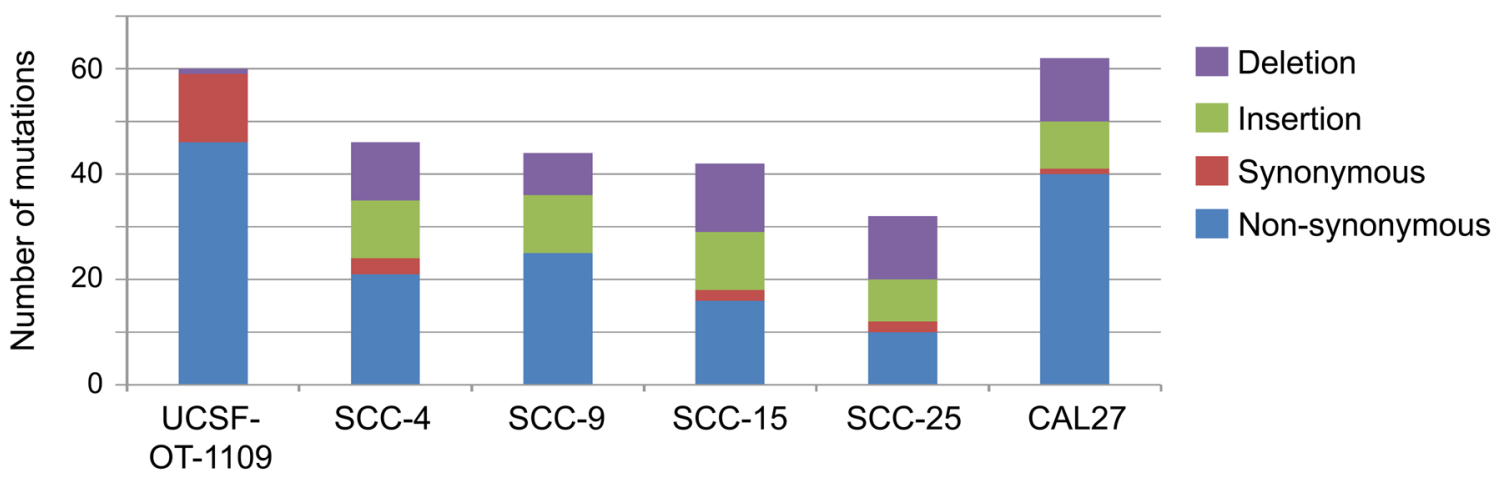

Figure 5. Unique mutational profile of UCSF-OT-1109. Genomic DNA extracted from UCSFOT-1109 \#21 underwent WES

(A) Distribution of non-synonymous and synonymous SNPs.

(B) Ratio between non-synonymous and synonymous SNPs in each chromosome.

(C) Mutational burdens of UCSF-OT-1109 and previously established OTSCC cell lines SCC-4, SCC-9, SCC-15, SCC-25, and CAL27 (obtained from the Cancer Cell Line Encyclopedia database). Numbers of non-synonymous and synonymous SNPs and insertion and deletion mutations are indicated graphically. 
A

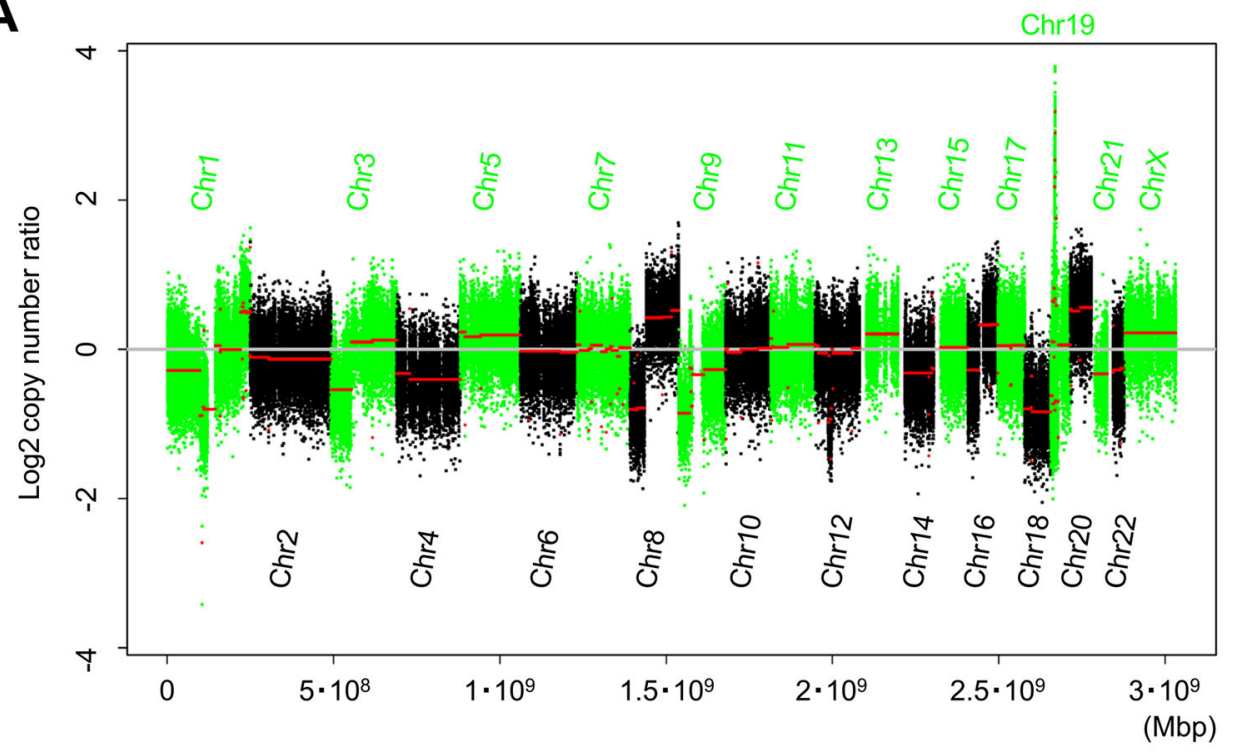

B

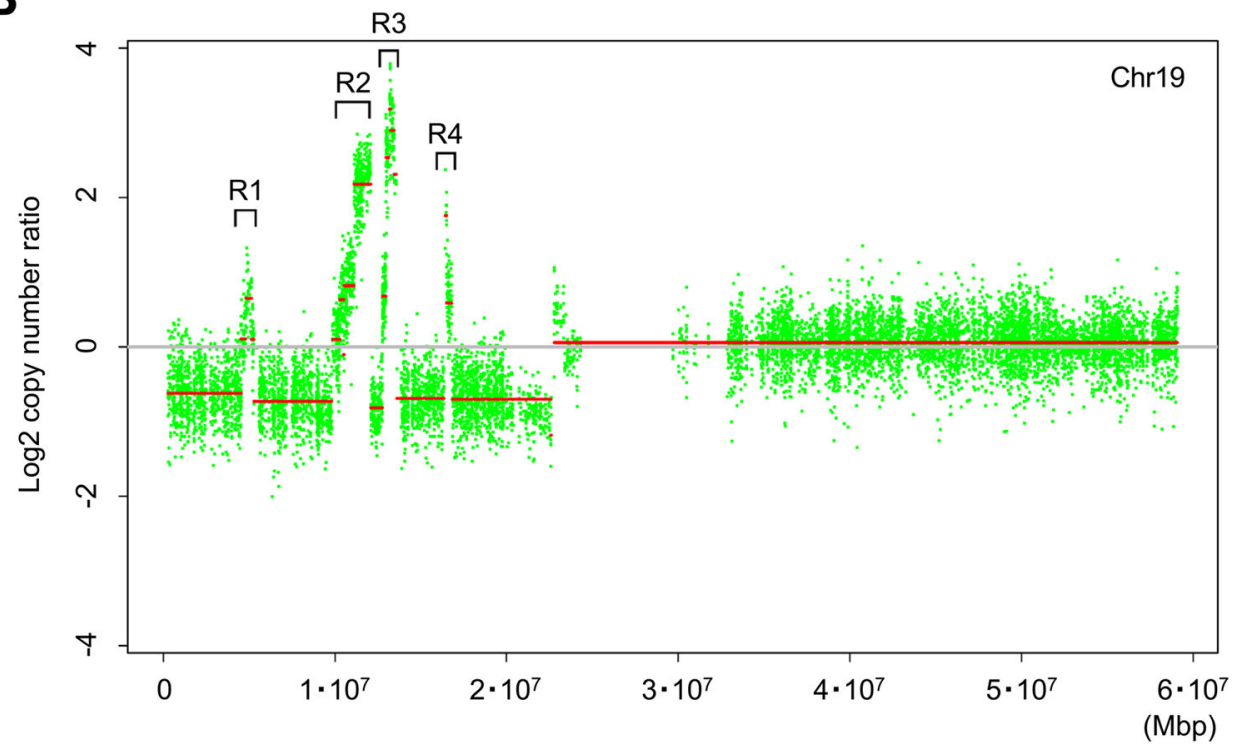

Figure 6. Distinctive focal amplifications in chromosome 19p of UCSF-OT-1109; WES copy number aberration analysis. Each dot represents sequencing probe

(A) The tumor genome with a high burden of both broad and focal DNA copy number aberrations.

(B) The magnified ideogram of chromosome 19. Four focal amplifications (R1-R4) in the short arm are shown. 


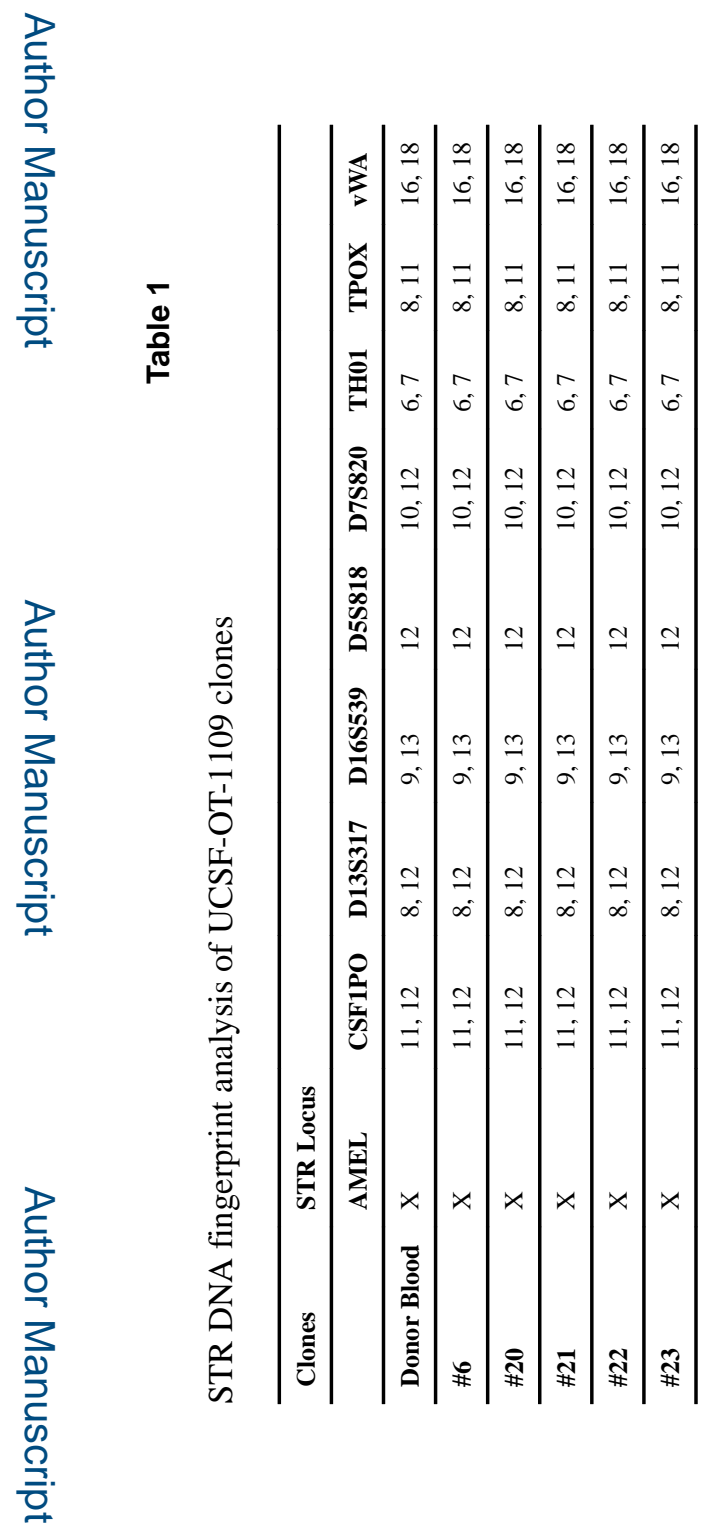

Oral Oncol. Author manuscript; available in PMC 2018 June 01. 